\title{
Brazilian Sugar in Domestic Retail: The Quality of Sugar Consumed in the State of Sao Paulo
}

\author{
Anna Flavia de Souza Silva, Sandra Helena da Cruz \\ Escola Superior de Agricultura Luiz de Queiroz, Universidade de Sao Paulo, Piracicaba, Brazil \\ Email: shcruz@usp.br
}

Received 23 February 2016; accepted 14 March 2016; published 17 March 2016

Copyright (C) 2016 by authors and Scientific Research Publishing Inc.

This work is licensed under the Creative Commons Attribution International License (CC BY).

http://creativecommons.org/licenses/by/4.0/

(c) (i) Open Access

\begin{abstract}
Brazil is the largest producer of sugarcane and its derivatives in the world, and one of the largest consumers of sugarcane derivatives. Sugar places a position of great prominence in Brazilian feed, either by direct consumption or as a component of industrialized products, from increasing consumption in the country. Sugar samples taken from local market were analyzed as the quality of table sugar consumed in the state of São Paulo (Brazil). The analysis of the parameters and basic attributes of characterization of sugar was according to the methodology developed by ICUMSA (2005; 2011) and ICUMSA modified by Copersucar (2002). Samples of sugar from this region showed that medium-low quality. It can be observed in fundamental aspects such as purity and insoluble residues, which were below the standard. In addition, it should be noted the difficulty of obtaining information about the limit values for each attribute, by virtue of Legislation not be assertive to the product and, also, the scientific studies have not been unified to present the specifics for each type of sugar.
\end{abstract}

\section{Keywords}

Table Sugar, Quality Parameters, Demerara Sugar, Brazilian Legislation

\section{Introduction}

Sugars are carbohydrates, which can be found in different types of chemical structures [1]. These compounds can be constituted by only one molecule of sugar (monossacharides) or can present structures with different types of polymerization (like oligossacharides or polissacharides) [2]. However, the term sugar refers itself to the sucrose, an oligossacharide constituted by the glycosidic ligation between glucose and fructose. Sugar (sucrose) can be 
obtained by the processing of saccharine raw materials, such as sugarcane, sweet sorghum and sugar beet [1]-[3].

The sugar is obtained from sugarcane through four main steps: the juice extraction in mills or diffusers; then the juice following for the treatment in order to remove impurities such as sand and bagasse debris and adjust the $\mathrm{pH}$ of the sugarcane juice [4] [5]. The next step is the concentration of the treated sugarcane juice by heating to remove water and the final one is the drying [4] [5]. The differences in conducting these steps promote the achievement of different types of sugar with specifications and standards different. The characteristics acquired during obtaining sugar impact the taste, flavor, color, smell and other attributes like purity and humidity [6].

Brazil is the largest producer of sugarcane in the world due to its production [7] [8]. This production was 632 million metric tons in the 2014/2015 crop, which originated 35 million metric tons of sugar [7]. Brazil is responsible for around $75 \%$ of all sugar produced in the world and about $70 \%$ is exported as a raw material [8] [9]. It is estimated that around 10 million metric tons are consumed in the country like table sugar or as an ingredient of food industry [9]-[11].

The fragile structure of Brazilian sugar specification led to the sugar mills to establish their own quality parameters. The specifications of sugar quality parameters are set by buyers and it is up to the industry operating to serve them, it happens when the products are for exportation or for large customers in the food market (major industries). For consumers, the Brazilian laws are being reviewed with the aim of promoting the characterization of all sugar types cold in the country.

The aim of this paper is to evaluate the physical-chemical parameters of four different types (crystal, refined, demerara and brown) of sugar acquired in markets of Piracicaba's region (Sao Paulo, Brazil). These parameters consist in chemical quality analysis of purity, color, humidity, insoluble residues and mineral content. After the chemical evaluation, the results will be contrasted the Brazilian Legislation for sugars, making a critically comparison with standards and the quality of sugar in domestic retail.

\subsection{Brazilian Pattern of Sugar Consumption}

The types of table sugar available in natura in Brazilian retail are crystal sugar (and its denominations, like crystal sifted sugar), the refined sugar, demerara and brown sugar, mainly. According to Family Budget Survey (POF) $2008 / 2009$, the type most consumed sugar is crystal one, that represents $61 \%$ of retail sugar trade, while refined sugar are responsible for $36 \%$ of retail sugar trade [12]-[14]. In terms of consumption, the crystal sugar presents mean per capita consumption of $8 \mathrm{~kg}$ per year, while refined sugar $3 \mathrm{~kg}$ per year [12].

Although the consumption of table sugar is still very representative in Brazilian feed, the consumption of sugar in Brazil is changing its pattern in the last decade [12]. The consumption of added sugar is increasing while table sugar consumption is decreasing itself [15]. This is probably due to the greater availability of industrialized products and lower cost of them. In addition, we can cite the increased purchasing power of lower social classes. The food industries that more demanding sugar as an ingredient are: the soft drinks, chocolates and confectionary and ice creams ones. They represent about 50\% of Brazilian sugar consumption [13] [14].

\subsection{Importance of the Chemical Analysis for Sugar Quality Control}

The chemical analyses in sugar are important for food industries, because of its role to guarantee the quality assurance throughout all food industry chain. They also can provide information about the quality of all steps involved in sugar production, what is very important for the mills, because it helps to control these steps. Finally, these analyses can contribute to assure the quality of the product according to its specifications, for final consumers.

The Quality Control System of the sugar mills has two types of chemical quality analyses: fundamental chemical quality analyses and complementary chemical analyses. The first group is important because they can define the main patterns and characteristics to sugar, as purity (polarization), color, humidity and insoluble impurities (also named impurities, insoluble solids or just residues) [6] [16]. The complementary analyses contribute to define important parameters, such as: alcoholic flakes, mineral content and starch concentration. These parameters can influence fundamental analysis and they are responsible for damages in sugar, mainly considering it as an ingredient [6] [16].

Refractive Apparent Purity (also known as polarization or simply purity) describes the capacity of sweeten other substance, besides of being an element that represents more quality of the product [6]. This parameter can be understood as the apparent weight percentage of sucrose. This measure is done in a solution of sugar and can be 
analyzed due to the deviation of the light in the polarized plane [3] [6] [16]. The result ranges in a scale of 0 (absence of sucrose in the solution) to 100 (100\% of sucrose in the solution) and the result is expressed officially in ${ }^{\circ} \mathrm{Z}$ (degrees Zucker) [6] [16].

The standard of sucrose concentration that assures the minimum value to white sugars of direct consumption is 99. $7^{\circ} \mathrm{Z}$ (that means $99.7 \%$ ), which the rest is constituted by impurities [6]. The exceptions to these standards are the types of sugar demerara and brown ones, due to difference in the processing, generally using less or none chemical additives to treat the cane juice, what keeps with similar features of sugarcane juice [17] [18]. Consequently, the purity are lower in these types than in the white ones [6] [17] [18]. However, the purity in these products should not been less than $90^{\circ} \mathrm{Z}$ (or 90\%), according to Brazilian standards [6] [16].

Color of sugar is expressed in Units (U.I.) of International Commission for Uniform Methods of Sugar Analysis (ICUMSA). It is an important attribute to sugar quality, because can influence the final characteristics of sugar uses (sweetness and color of food) [6] [18]. Color is direct related with the size of particulate material (as lower more white), what it is crucial for the quality of crystal and refined types [6]. The non-standardized granulometry can causes increase in sugar color [6] [18]. This parameter also impacts directly the industries of soft drinks, candies and confectionaries and ice creams because it can interfere in the final color of these products [6] [18].

Humidity analysis (expressed in percentage) is based in the drying of sugar, under specific conditions of time and temperature [18]. The final result is obtained when weight loss (due to the water removal) becomes constant [18]. Humidity in sugar is one of the more important parameters, because influences the stability, quality (with the appearance of clods and sugar stones) and in the composition of sugar [19] [20]. The analysis also represents a parameter to evaluate the microbiological contamination due to its higroscopicity (capacity of absorbing water from an environment that offers relative humidity greater than balance) [3] [19]-[22]. This property of sucrose is undesirable in function of dextran formation, polymeric material secreted by bacteria of genus Leuconostoc that transforms sucrose in glucopyranosyl (Figure 1) [19] [21]. The humidity range to sugar is $0.1 \%$ to $3.3 \%$ depending of the type sugar, being tolerated until 5\% to raw sugar [18] [19] [23].

Insoluble residues are composed by particulate material, which is in suspension or precipitate in a solution of sugar [6]. Usually, the residues are composed by sugarcane soots, sand, metallic residues, silica and others [6] [24]. As lower is its concentration in sugar, higher is the quality of the product and the process [6] [16] [24]. This aspect is important considering the unit operation of decantation, during the treatment of juice. Sugars, generally, have to present residue content of 10 to $60 \mathrm{mg} \cdot \mathrm{kg}^{-1}$ [6]. The higher concentrations occur normally in sugars which unit operations of treatment of sugarcane juice and decantation less aggressive [24]-[26]. Insoluble residues are impurities that consumers can recognize, both visually and by taste [6] [24] [26].

Conductivity ashes analysis consists in removing organic matter of sugar, leaving only the inorganic residue (also known as mineral residues, like calcium, iron, magnesium etc.). This parameter allows characterizing the mineral content of the product by measuring the electric current of the minerals in sugar solution. Higher concentration of ashes in sugar can represent problems during its production, mainly in the step like crystallization and purification. The ashes are related with important parameters of sugar, like color and purity, because it can affect then [6] [25] [26].<smiles>OC[C@H]1O[C@H](O[C@@H]2[C@@H](CO)O[C@H](O[C@@H]3[C@@H](CO)O[C@H](O[C@@H]4[C@@H](CO)O[C@H](O)[C@H](O)[C@H]4O)[C@H](O)[C@H]3O)[C@H](O)[C@H]2O)[C@H](O)[C@@H](O)[C@@H]1O</smiles>

Figure 1. Molecule of glucopyranosyl. 


\section{Material and Methods}

\subsection{Brazilian Legislation for Sugars}

It was consulted Brazilian Law for specifications of sugar and sugar products, in the website of National Commission for Norms and Standards for Food of National Sanitary Surveillance. The basis Laws are the Resolution of National Commission for Norms and Standards for Food of National Sanitary Surveillance (Resolução CNNPA/ANVISA) n 12, published at July 24 ${ }^{\text {th }}, 1978$ and Resolution Board of National Sanitary Surveillance (RDC/ANVISA) n 271, published at September, 22 ${ }^{\text {nd }}$, 2005. RDC 271/2005 is more complete than CNNPA $12 / 1978$ mainly in which concerns the standards for sugar quality, although the both are very fragile to the needs of qualifying sugar [27] [28].

\subsection{Sugar Samples}

Thirteen samples of sugars consumed in state of Sao Paulo were obtained in Piracicaba region (Sao Paulo, Brazil) in local markets. The sugar types more consumed in the city were studied by Corniani \& Cruz (2011) and were made a decreasing scale, beginning with the more consumed type [29]. Therefore, according to this scale was projected the number of samples of each type of sugar, being 6 of crystal sugar (named by C1 to C6), 3 of refined sugar (named by R1 to R3), 2 of demerera and brown sugar (named, respectively by D1, D2, B1, B2). We reserve the right to not disclose the trade name of the samples.

\subsection{Physical-Chemical Analysis}

The methodology applied in the analysis were the fixed by ICUMSA (2011) and ICUMSA (2005). Some analysis were applied with adaptations to Brazilian sugar fixed by "Handbook of Methods for Sugar Analysis", elaborated by Copersucar (2002), such as color ICUMSA and purity [16] [30] [31].

1. Refractive Apparent Purity (Purity): $26 \mathrm{~g}$ of sugar were dissolved in $100 \mathrm{~mL}$ of deionized water. The solution was analyzed in a saccharimeter Sucromat VIS/NIR (Anton Paar, Graz, Austria). The results are expressed at ${ }^{\circ} \mathrm{Z}$ and at $20^{\circ} \mathrm{C}$.

2. Color ICUMSA: $25 \mathrm{~g}$ of sugar were weight and dissolved in $25 \mathrm{~g}$ of buffer TEA (Triethanolamin/ $\mathrm{HCl}, 0.1 \mathrm{M}$, $\mathrm{pH}$ 7.0). Both were weight in balance (Radwag PS RI, USA). After dissolution, the liquid was filtered under vacuum using cellulosic Millipore $0.45 \mu \mathrm{m}$ membrane. Refratometric Brix of solution was determined in a refratometer (Atago Palette mod. PR101, Bellevue, United States ) and its $\mathrm{pH}$ correct to $7.0 \pm 0.1 \mathrm{in} \mathrm{pH}$ meter (Digimed mod DMPH-1, Sao Paulo, Brazil) with a solution of NaOH 0,1M. The absorbance of the solution was measured in spectrophotometer (FEMTO 700S, Sao Paulo, Brazil) at 420nm. TEA buffer was used as blank solution. The color was calculated according Equation (1).

$$
\text { Color }=1000 \mathrm{Abs} /(\mathrm{b} \times c)
$$

Which:

Abs, absorbance measured in the sample

$b$, intern diameter of cell

$c$, concentration of the filtered solution, $\mathrm{g} \cdot \mathrm{mL}^{-1}$, in function of its corrected ${ }^{\circ}$ Brix of 0.989 .

3. Humidity: $5 \mathrm{~g}$ of sugar were weight in a balance (Radwag PS RI, USA) and after dried at $105^{\circ} \mathrm{C}$ during $1 \mathrm{~h}$ in stove (Marconi SE, mod. 32012, Brazil). After cooling in dissiccator, the sample was weighted until obtaining constant weight. Humidity (\%) was calculated by the difference of weight (before and after drying) multiplied per 20.

4. Insoluble Residues: 100 g of sugar were weighted in balance (Radwag PS RI, USA) and dissolved in 200 $\mathrm{mL}$ of deionized water. The moisture was homogenized and the solution was filtered under vacuum. The filter (Nalgon 3 micras, diameter $15 \mathrm{~cm}$, Brazil) was previously dried in stove (Marconi SE, mod. 32012, Brazil) under the condition of $105^{\circ} \mathrm{C}$ per 5 minutes. After filtration, the filter was dried again in the stove, under the same conditions. The quantity of insoluble residues (\%) was obtained by the difference of weight.

5. Conductivity Ashes: $5 \mathrm{~g}$ of sugar were dissolved in $100 \mathrm{~mL}$ of deionized water. The solution were analyzed in conductivity meter (Tecnal, mod 4MP, Brazil). 


\section{Results and Discussion}

\subsection{Analysis of Brazilian Legislation and Regulamentation for Sugars}

The fragile structure of sugar specification was recognized by the analysis of sugar Legislation and also by consulting the website of sugar traders and mills [14] [24] [26]-[28]. It was possible notice in these researches that the mills presents to the consumers the Legislation concerning to microbiological aspects (by citing the Resolution Board of National Sanitary Surveillance (RDC/ANVISA) n. 12, published at January12 ${ }^{\text {th }}$, 2001) and contaminants ones (Ordinance of the Health Surveillance Secretariat n 685, published at August 27 ${ }^{\text {th }}$, 1998) [33] [34].

Due to the lack of government specifications for quality standards for sugar, the sugar mills set up their own parameters. These ones were obtained from ICUMSA (2005), ICUMSA (2011) and manual methods developed by Copersucar (2002) that adapted to Brazilian case the ICUMSA methodologies for products for exportation or for large customers in the food market (major industries). The specifications of sugar quality parameters are set by buyers and it is up to the industry operating to serve them [16] [26] [30]-[32].

Brazilian Laws are being reviewed with the aim of promoting the characterization of all sugar types sold in the country. An example of this new reality is the Ordinance $n$ 152, published at December $6^{\text {th }}, 2013$ [35]. This new regulamentation begins to provide the Normative Ruling Bill to approve the Sugar Technical Regulation, defining its official classification standard, with the identity and quality requirements, sampling, method of presentation and marking or labeling [35]. This regulatory project is critical to the standardization of the product and will certainly be a gain for all those involved in the chain of production and consumption of sugar, when approved and be in force.

The usefulness of this application and domestic regulations will be appreciated, for example, to characterize types of sugar as demerara or organic, which do not have defined clearly the quality parameters by the current regulatory acts. Furthermore, this can contribute to the uniformity of the product, to control the high variability of the aspects of chemical quality existing between the same types of sugar (in some cases, the great variability within the trademark) and also to validate limits and specifications established by research centers.

\subsection{Physical Chemical Results}

The results of fundamental analysis and complementary chemical assays were shown in the Table 1 and they point out the quality of consumed sugar in state of Sao Paulo, Brazil. It is directly associated to the regulation norms, as explained before.

Table 1. Physical chemical assays to the measured quality attributes of sugar samples, in triplicate, also presenting the standard deviation.

\begin{tabular}{cccccc}
\hline Sugar & Purity $\left({ }^{\circ} \mathbf{Z}\right)$ & Color (UI) & Humidity (\%) & Insoluble Residues $\left(\mathbf{m g} \cdot \mathbf{k g}^{-\mathbf{1}}\right)$ & Conductivity Ashes (\%) \\
\hline D 1 & $93.09 \pm 0.08$ & - & $0.20 \pm 0.02$ & $2700+100$ & $0.05 \pm 0.001$ \\
D 2 & $98.88 \pm 0.20$ & - & $0.26 \pm 0.01$ & $2400+80$ & $0.06 \pm 0.002$ \\
C 1 & $98.87 \pm 0.10$ & $93 \pm 1$ & $0.17 \pm 0.03$ & $2700+75$ & $0.04 \pm 0.006$ \\
C 2 & $96.18 \pm 0.08$ & $5 \pm 1$ & $0.37 \pm 0.03$ & $3100+120$ & $0.02 \pm 0.004$ \\
C 3 & $99.72 \pm 0.30$ & $271 \pm 20$ & $18.00 \pm 2$ & $2100+90$ & $0.06 \pm 0.003$ \\
C 4 & $98.29 \pm 0.07$ & $108 \pm 10$ & $0.52 \pm 0.04$ & $3400+190$ & $0.07 \pm 0.002$ \\
C 5 & $100.00 \pm 0.05$ & $31 \pm 3$ & $0.20 \pm 0.05$ & $2800+90$ & $0.02 \pm 0.004$ \\
C 6 & $99.26 \pm 0.06$ & $94 \pm 6$ & $0.39 \pm 0.03$ & $3300+95$ & $0.02 \pm 0.003$ \\
R 1 & $95.96 \pm 0.20$ & $37 \pm 4$ & $0.67 \pm 0.06$ & $1400+100$ & $0.01 \pm 0.002$ \\
R 2 & $93.39 \pm 0.10$ & $50 \pm 5$ & $1.47 \pm 0.4$ & $1400+90$ & $0.02 \pm 0.006$ \\
R 3 & $99.70 \pm 0.06$ & $30 \pm 3$ & $0.81 \pm 0.06$ & $1300+95$ & $0.09 \pm 0.005$ \\
B 1 & - & - & $5.00 \pm 0.8$ & $*$ & $1.87 \pm 0.07$ \\
B 2 & - & - & $20.00 \pm 3$ & $*$ & $0.65 \pm 0.05$ \\
\hline
\end{tabular}

D: demerara sugar, C: crystal sugar, R: refined sugar, B: brown sugar; *limiting factors-chemical analysis not applicable to the sample. 
Purity assays (Table 1) allow to conclude that the great part of sugar samples are not in accordance to the minimum standard of quality established by ICUMSA (2011), Copersucar (2002) and also in the commodities contract for sugar (Table 2) [16] [30] [31]. Inside each group of sugar, there are specifications that give the label of "sugar types". To feature crystal sugar in "sugar types", many parameters that are considered and the most important are: purity, insoluble residues, concentration of Sulphur dioxide and color. One label of sugar type can also be subdivided and for that are considered the same above [6] [30].

We analyzed these labels only for crystal sugar, due to this sugar being the most consumed in the region analyzed (Figure 2). The data analysis showed the variability of sucrose content in sugar in the samples, what can be related to the high content of insoluble residues registered to the same samples (Table 1), and what represents another problematic evidence of the insufficient standardization for these two fundamental parameters.

It is important to highlight that low purity impacts directly in the sweetness of sugar, turning lower its perception for the consumers. In addition, for food industries this can impact in the quality of products (mainly soft drinks, candies and confectioneries) also causing changes in the stability and viscosity of their products [6] [38]. Besides the insoluble residues, other substances can affect this parameter, such as the starch and correlated molecules (e.g., amylopectin) and high content of ashes. For the mills, the final purity of sugar is a key to constantly monitor process quality, because lower results for this parameter can predict problems during sugar processing, mainly in the steps of sugarcane juice treatment and its purification [6] [38] [39].

The color assays showed satisfactory results (Table 1). Almost all samples of white sugars analyzed (refined and crystal) can be classified like sugar Type 1. The exceptions are the samples C3 (that can be classified like Type 3) and C4 (that can be classified like Type 3). Although the good results, it necessary to work to improve the color control in the industries because some samples presented color results in the maximum limit established to ICUMSA (2011) and Copersucar (2002). This aspect is another point that the standardization by Brazilian Legislation should aid to control. This analysis is not applicable to demerara and brown sugar and, because of that, there are no results measured for that. It is important to highlight that these types of sugar are naturally darker than crystal and refined due to their processes. In this case is not correct associate low quality to these products because, in this case, this color is due to the color compounds of sugarcane [4] [6] [16] [31].

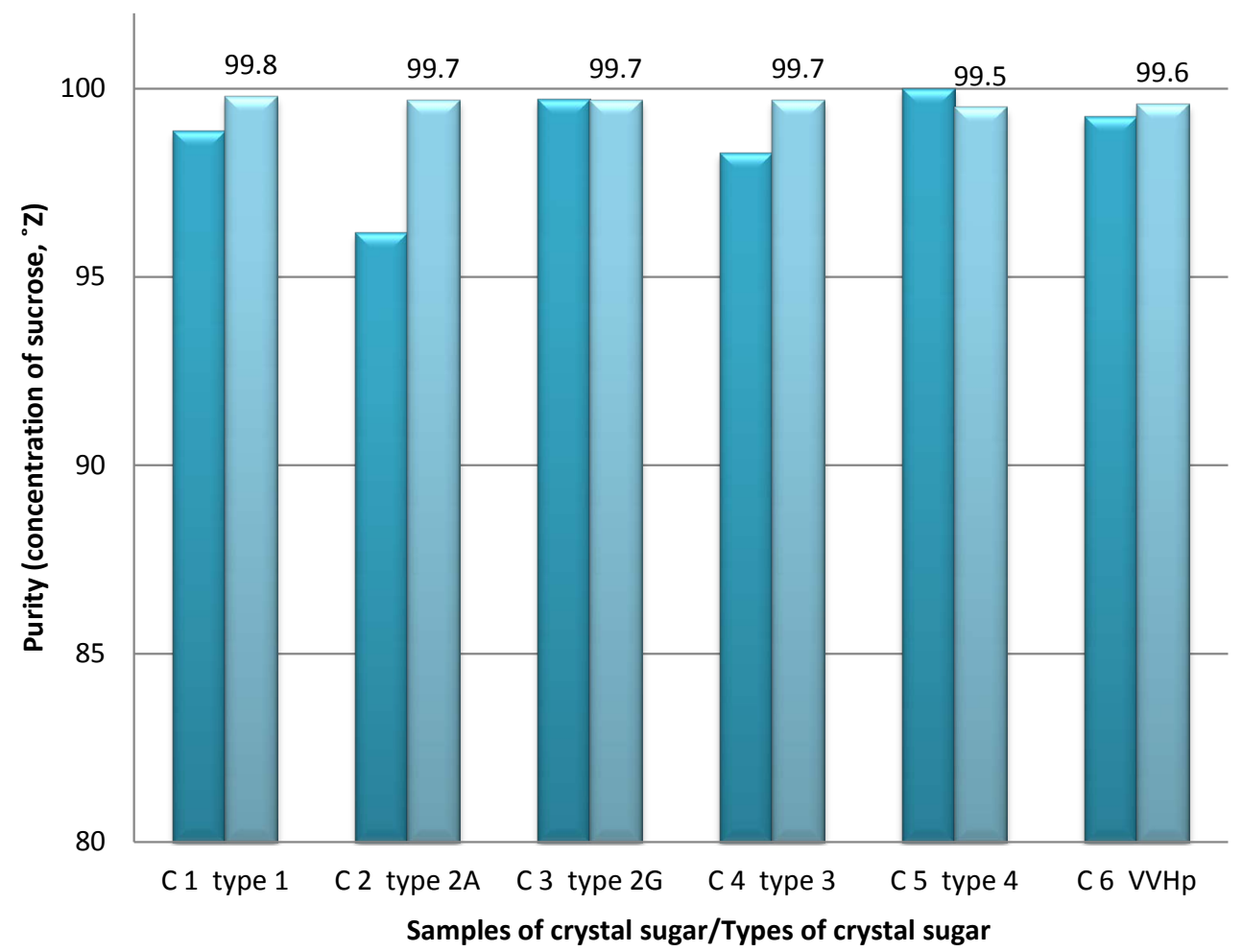

Figure 2. Variability of sucrose content in sugar samples (blue) contrasted to the minimum concentration of sucrose (cyan) recommended to each sugar type by Copersucar [16]. 
Table 2. Sugar types and their standards.

\begin{tabular}{|c|c|c|c|c|}
\hline & Sugar & Minimum Purity $\left({ }^{\circ} Z\right)$ & Maximum of Color (UI) & Ashes content (\%) \\
\hline \multirow{8}{*}{$\begin{array}{l}\text { Copersucar (2002) } \\
\text { recommendations }{ }^{1,2}\end{array}$} & Crystal Type 1 & 99.8 & 100 & $<0.07$ \\
\hline & Crystal Type 2A & 99.7 & 150 & $<0.10$ \\
\hline & Crystal Type 2G & 99.7 & 150 & $<0.15$ \\
\hline & Crystal Type 3 & 99.7 & 200 & $<0.15$ \\
\hline & Crystal Type 4 & 99.5 & 400 & $>0.15$ \\
\hline & Refined & 99.8 & 45 & $<0.04$ \\
\hline & Raw & 99.6 & 450 & Not available \\
\hline & Sugar & Minimum Purity $\left({ }^{\circ} \mathrm{Z}\right)$ & Maximum of Color (UI) & Ashes content (\%) \\
\hline \multirow{3}{*}{$\begin{array}{l}\text { ICUMSA (2011) } \\
\text { recommendations }{ }^{3}\end{array}$} & Refined sugar & 99.8 & 45 & Maximum 0.04 \\
\hline & Raw and brown sugar & 96 & 600 until 1200 & Not defined \\
\hline & Sugar & Minimum Purity ( $\left.{ }^{\circ} \mathrm{Z}\right)$ & Maximum of Color (UI) & Ashes content (\%) \\
\hline \multirow{3}{*}{$\begin{array}{l}\text { Commodity contract } \\
\text { specifications }^{\mathrm{a}}\end{array}$} & Refined Sugar & 99.8 & 45 & Maximum 0.04 \\
\hline & Crystal Sugar & 99.6 & 150 & Maximum 0.07 \\
\hline & Raw Sugar & 94 & 600 until 1200 & Not defined \\
\hline
\end{tabular}

${ }^{1}$ Copersucar (2002) [16], ${ }^{2}$ Oliveira et al. (2007) [6], ${ }^{3}$ ICUMSA (2011) [28], ${ }^{\mathrm{a}}$ Genesis Group (2015) [36] and ${ }^{\mathrm{a} T h e}$ Ice Market (2016) [37]. ${ }^{\mathrm{a}}$ Commodity contract specifications according data presented by Genesis Group (2015) and The Ice Market (2016).

Color is an important attribute because can influence final aspects of sugar application, mainly in the color of the food and the sweetness perception. Insoluble residues and the types of mineral that compound the ashes can influence the color, turning it higher, i.e., more yellow [6]. As darker is a sugar, less preferred it is for the consumers and, due to this behavior, it can be labeled as a sugar with low quality [6] [38] [39]. In addition, sugar color is also influenced by the carbonized particle content in the product, which are entrained in the process as result of failures in the cleaning process in the equipment and machinery [39] [40].

In relation to humidity assays, it was observed that there is a controversy context because of the wide range of water concentration in the product. Although Copersucar (2002) established standards to try to help the mills to organize the standards of its products, the lack of standardization and identity for sugars by Brazilian Legislation contributes for this complicated panorama [16]. This context also occurs into industrial scale and is promoting the production and utilization of liquid sugar, which represents a lower problem for food industries due to the standardized concentration of the product (minimum concentration is $65^{\circ}$ Brix).

We considered the reference of maximum of $0.1 \%$ of humidity for white sugars (crystal and refined sugar) and 3.3\% for brown sugar. ANVISA recommends for maximum of humidity what was measured and indicated by Brazilian Table of Food Composition (TACO), what can be until $5 \%$ of humidity to brown sugar. In this sugar type is necessary more control for this attribute, because it can promote undesirable degradation reactions in the products, like microbial contamination and turn the sugar darker than it was acceptable [30] [32]. Unfavorable environmental conditions, like high relative humidity of environment and also intrinsic properties of sugar, like higroscopicity, can cause damages in the results, overestimating them [3] [24].

It was possible to notice that all samples of white sugars are not in accordance to the standard adopted, what can be explained due to sugar capacity of higroscopicity and the incorrect storage in retail. Another reason for that, although less likely, is an inadequate process of sugar drying. For brown sugar results, the same conditions explains the fact, although is easier that the failure is during the concentration of sugar syrup and the drying process, because of Brazilian brown sugar is produced by artisanal producers, mostly by family farming [24] [30]. There are no studies about the acceptable limit for humidity in demerara sugar. Due to its similarity to raw sugar, if we consider the maximum of $0.15 \%$ of humidity, it is possible to classify the samples as in discordance to the standards recommended by ICUMSA (2011) and Copersucar [16] [24] [31] [34] [35]. 
The insoluble residues tolerated in sugar varies among 10 to $60 \mathrm{mg} \cdot \mathrm{kg}^{-1}$, according to Copersucar (2002) [6] [16]. This occurs due to the difference in the processes of different sugar [4] [5]. However, the residues content in the samples (Table 1) analyzed were, in average, 45 times superior to the maximum tolerated (Figure 3). Brown sugar was not analyzed because there are no features in Brazilian Laws or by Copersucar [16] for this component, what turns difficult the comparison of results.

The causes for these results can be failures in the quality processes control in the mills or in other parts of sugar chain because it is important to clear that are enterprises that buy raw sugar to refine, putting their brands in the product. The fragile standardization impacts also in this activity and trade relation. In addition, inefficiencies in decantation and flocculation can explain the results, because these two unitary operations (they composes treatment and purification steps, respectively) are responsible by the elimination of impurities (like sand, bagacillo and others) in sugar cane juice [4] [5]. It is known that the residues affects the color and the perception of sweetness, mainly, reducing the quality of the products and representing sensory challenges to food industry and for consumer satisfaction in relation to industrialized food and its uses [6].

During sample preparation to insoluble residues analysis, it was possible to notice insoluble particulate material and small black dots in the aqueous solution, generating precipitates in the solution. Concomitantly, it was observed darkening in the sucrose solution (shade between dark yellow and brown). This can be explained due to chemical reactions of dehydration, fragmentation and polymerization of the sucrose molecule in solution caused by high temperatures (mainly over $100^{\circ} \mathrm{C}$ ) during sugar process, concentration of sugar syrup (as more concentrated more trends to be darker). It can caused by changes in $\mathrm{pH}$ in sugarcane juice or sugar syrup (mainly when in alkaline gradient but, it also can happens in acid conditions but at a slower speed) [40] [41].

The maximum limit of conductivity ashes is established according to sugar types (Table 2). The analyses of the results of all samples (Table 1) allow to realize that all samples are in accordance to the standards established by Copersucar (2002) and in the literature [23] [25]. It is important to highlight that are no defined limits for raw sugar and brown sugar in international trade, what can represents problems in standardization of sugar. Although ashes are a complementary attribute to sugar quality, they impact direct the quality of this product, in the already mentioned attributes of purity, insoluble residues and promoting the darkening of sugar catalyzing the reactions mentioned. In addition, high concentration of ashes can indicates excess of potassium, mineral that difficult the crystallization of sucrose in sugar cane juice besides promote alterations in sensory features (improper and undesirable flavor) [6] [21] [25].

\section{Conclusions}

Sugar consumed in the state of Sao Paulo presents, generally, low to medium quality because the two more important standards that describe the quality in the product (purity and insoluble residues) are not according to the minimum standard described by Copersucar, as well as by ICUMSA and in sugar contracts. It is interesting to notice that this is a problem of Brazilian retail, because some samples are not produced in the city and also in Sao Paulo, although are consumed and commercialized in Piracicaba city.

Although the standards of chemical quality analysis of sugar are observed singly, it is important to notice and analyze then considering their direct relation. This condition results in the interaction of the attributes, which are indispensable to characterize and evaluate sugar quality.

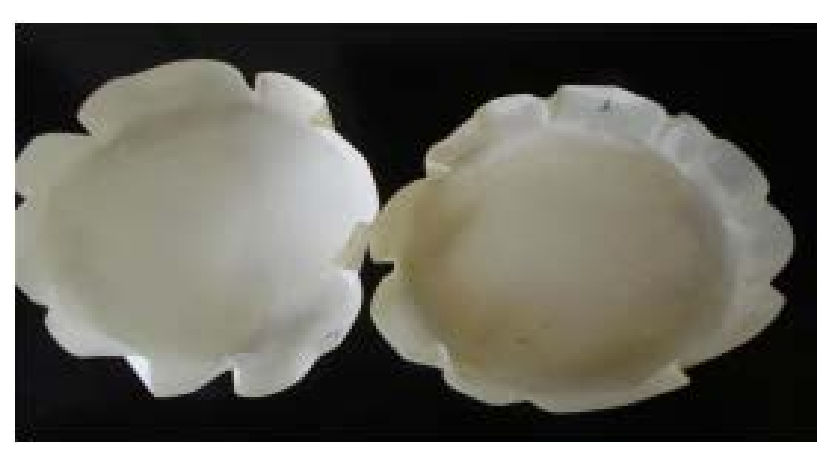

Figure 3. Filter paper before (left) and after (right) insoluble residues analysis for sample C4. 
The fragile patterns regulated by Brazilian Laws are the main cause that prevents the standardization of the sugar in retail. This fact allied to the natural heterogeneity of this product can explain part of deviations for the same attribute in the same types of sugar. It is necessary for more researches and scientific material in this area to support the Government with the standardization of the product, and also with the inspection of sugar in retail.

\section{References}

[1] European Union (EU) (2012) Guidance Document for Competent Authorities for the Control of Compliance with EU Legislation. http://ec.europa.eu/food/safety/docs/labelling_nutrition-vitamins_minerals-guidance_tolerances_1212_en.pdf

[2] International Union of Pure and Applied Chemistry (IUPAC) (2006) Compendium of Chemical Terminology/Gold Book. http://goldbook.iupac.org/PDF/goldbook.pdf

[3] Damodaran, S., Parkin, K. and Fennema, O.R. (2008) Fennema’s Food Chemistry. 4th Edition, Taylor \& Francis, Boca Raton.

[4] Rein, P. (2007) Cane Sugar Engineering. Bartens, Berlin.

[5] Payne, J.H. (1982) Unit Operations in Cane Sugar Production. Elsevier Scientific Pub. Co., Amsterdam.

[6] Oliveira, D.T., Esquiaveto, M.M.M. and Silva Jr., J.F. (2007) Sugar Specification Parameters and Their Impact on the Food Industry. Ciência e Tecnologia de Alimentos, 27, 99-102. http://dx.doi.org/10.1590/S0101-20612007000500018

[7] Brazil. Companhia Nacional de Abastecimento (2015) Acompanhamento da safra brasileira de cana-de-açúcar 2015/ 2016. Terceiro Levantamento.

http://www.conab.gov.br/OlalaCMS/uploads/arquivos/15 1217090329 boletim cana portugues - 3o lev - 1516.pdf

[8] Chauhan, M.K., Varun, S.C. and Suneel Kumar S. (2011) Life Cycle Assessment of Sugar Industry: A Review. Renewable and Sustainable Energy Reviews, 15, 3445-3453. http://dx.doi.org/10.1016/j.rser.2011.04.033

[9] Brazilian Sugarcane Industry Association (UNICA) (2016) Production Data: Sugarcane Production and Processing. http://www.unicadata.com.br/historico-de-producao-e-moagem.php?\%20idMn=32\&tipoHistorico=4

[10] Behling, R.R., Ed. (2013) Brazilian Sugar Cane Yearbook 2013. Gazeta, Santa Cruz do Sul.

[11] Behling, R.R., Ed. (2014) Brazilian Sugar Cane Yearbook 2014. Gazeta, Santa Cruz do Sul.

[12] Brazil. Instituto Brasileiro de Geografia e Estatística (IBGE) (2011) Pesquisa de Orçamentos Familiares 2008/2009. http://www.ibge.gov.br/home/estatistica/populacao/condicaodevida/pof/2008_2009_analise_consumo/pofanalise_2008 2009.pdf

[13] Neves, M.F., Trombin, V.G. and Consoli, M.A. (2013) Mapeamento e Quantificação do Setor Sucroenergético: Mapeamento e Quantificação da Safra 2013/2014. http://www.unica.com.br/download.php?idSecao=17\&id=25818107

[14] Dias, V. (org.) (2015) Raízen Sustainability Report. http://www.raizen.com.br/sites/default/files/relatorio-ingles 211215 02.pdf

[15] Levy, R.B., Claro, R.M., Bandoni, D.H., Mondini, L. and Monteiro, C.A. (2012) Availability of Added Sugars in Brazil: Distribution, Food Sources and Time Trends. Revista Brasileira de Epidemiologia, 15, 3-12. http://dx.doi.org/10.1590/S1415-790X2012000100001

[16] Centro de Tecnologia Copersucar (CTC/Copersucar) (2002) Manual de Métodos de Análises para Açúcar. Divisão Central de Laboratório de Análise e Controle de Qualidade (CTTI), Piracicaba.

[17] Brazil. National Sanitary Surveillance (2003) Resolution Board of National Sanitary Surveillance (2003) n 175. http://portal.anvisa.gov.br/wps/wcm/connect/efabae00474580fc8d11dd3fbc4c6735/RDC_175_2003.pdf?MOD=AJPE $\underline{\mathrm{RES}}$

[18] Cano, C.B., Nagato, L.A.F. and Duran, M.C. (2005) Açúcares e produtos correlatos. In: Métodos físico-químicos para análise de alimentos, 4th Edition, Instituto Adolfo Lutz, Brasília, Chapter 7, 321- 343.

[19] Pereira, J.A.M. and Queiroz, D.M. (1987) Higroscopia. Centreinar-UFV, Viçosa.

[20] Carlos, L.A., Resende, J.V. and Cal-Vidal, J. (2005) Reduction of Freeze-Dried Powder Hygroscopicity by Inducing Crystallization in Model Fruit Sugar Solutions. Brazilian Journal of Food Technology, 8, 163-173. http://www.ital.sp.gov.br/bj/artigos/brazilianjournal/free/p05201.pdf

[21] Aquino, F.W.B. and Franco, D.W. (2008) Dextrans in Sugars from São Paulo State. Química Nova, 31, $1034-1037$. http://dx.doi.org/10.1590/S0100-40422008000500016

[22] Parazzi, C., Jesus, D.A., Lopes, J.J.C. and Valsechi, O.A. (2009) Análises microbiológicas do açúcar mascavo. Bioscience Journal, 25, 32-40. http://www.seer.ufu.br/index.php/biosciencejournal/article/view/6906/4573 
[23] Núcleo de Estudos e Pesquisas em Alimentação (NEPA) (2011) Tabela brasileira de composição de alimentos (TACO). https://www.unicamp.br/nepa/taco/contar/taco_4_edicao_ampliada_e_revisada.pdf?arquivo=taco_4_versao_ampliada_ e_revisada.pdf

[24] Alto Alegre Company (2016) Produtos. http://www.altoalegre.com.br/produtos.aspx

[25] Cecchi, H.M. (2003) Fundamentos teóricos e práticos em análise de alimentos. 2nd Edition, Editora da UNICAMP, Campinas.

[26] Tereos Group: Açúcar \& Energia Brasil (2015) Produtos. http://www.aguarani.com.br/produtos/

[27] Brazil. National Sanitary Surveillance (1978) Resolution Board of National Sanitary Surveillance (1978) n 12. http://portal.anvisa.gov.br/wps/wcm/connect/e57b7380474588a39266d63fbc4c6735/RESOLUCAO_12_1978.pdf?MO D=AJPERES

[28] Brazil. National Sanitary Surveillance (2005) Resolution Board of National Sanitary Surveillance (2005) $n^{\circ} 271$. http://portal.anvisa.gov.br/wps/wcm/connect/ca624500474594079ba5df3fbc4c6735/RDC_271_2005.pdf?MOD=AJPE RES

[29] Corniani, L.S. and Cruz, S.H. (2011) Levantamento dos diferentes tipos de açúcar comercializados na cidade de Piracicaba/SP. Simpósio Internacional de Iniciação Científica da Universidade de São Paulo, São Paulo, 1445. http://www.acucarpurinha.com.br/anuario_da_cana.pdf

[30] International Commission for Uniform Methods of Sugar Analysis. ICUMSA (2005) ICUMSA Methods Book 2005. Bartens, Berlin.

[31] International Commission for Uniform Methods of Sugar Analysis. ICUMSA (2011) ICUMSA Methods Book 2011. Bartens, Berlin.

[32] Usina São Domingos (2015) Açúcar VHP e Cristal. http://www.usinasaodomingos.com.br/site/?pagina=acucar

[33] Brazil. National Sanitary Surveillance (2001) Resolution Board of National Sanitary Surveillance (2001) n 12. http://portal.anvisa.gov.br/wps/wcm/connect/a47bab8047458b909541d53fbc4c6735/RDC 12 2001.pdf?MOD=AJPE $\underline{\mathrm{RES}}$

[34] Brazil. National Sanitary Surveillance (1998) Ordinance ${ }^{\circ} 685$. http://portal.anvisa.gov.br/wps/wcm/connect/8c494f804745801a8c00dc3fbc4c6735/PORTARIA+N+\%C2\%BA+685,+ DE+27+DE+AGOSTO+DE+1998.pdf?MOD=AJPERES

[35] Brazil. Ministry of Agriculture, Livestock and Supply. Secretary Of Defense Agriculture (2013) Ordinance $n^{\circ} 152$. http://www.lex.com.br/legis 25168439 PORTARIA N 152 DE 6 DE DEZEMBRO DE 2013.aspx

[36] Genesis Group. Sugar Specifications. http://www.genesisny.net/Commodity/Sugar/SSpecs.html

[37] The Ice Futures. Sugar Futures. https://www.theice.com/products/23/Sugar-No-11-Futures

[38] Generoso, W.C., Borges, M.T.M.R., Ceccato-Antonini, S.R., Marino, A.F., Silva, M.V.M., Nassu, R.T. and VerrumaBernardi, M.R. (2009) Physical-Chemical and Microbiological Evaluation of Commercial Brown Sugar. Revista do Instituto Adolfo Lutz, 68, 259-268. http://revistas.bvs-vet.org.br/rialutz/article/download/6960/7178

[39] Lemos, R.L. (2012) Influência em diferentes teores de dextrana e amido em açúcar cristal na formação de flocos em soluções ácidas carbonatadas e soluções alcoólicas. M.Sc. Thesis, Universidade Federal de Ponta Grossa, Ponta Grossa. (In Portuguese)

[40] Oh, S.H., Lee, Y.S., Kim, J.H., Kim, J.H., Lee, J.W., Kim, M.R., Yook, H.S. and Byun, M.W. (2006) The Effect of $\gamma$-Irradiation on the Non-Enzymatic Browning Reaction in the Aqueous Model Solutions. Food Chemistry, 94, 420-427. http://dx.doi.org/10.1016/j.foodchem.2004.11.034

[41] Podadera, P. (2007) Study of the Properties of Inverted Liquid Sugar Processed with Gamma Radiation and Electron Beam. Ph.D. Thesis, University of Sao Paulo, Sao Paulo. (In Portuguese) 